\title{
橈骨遠位端関節内骨折（粉粋型）の治療成績
}

\author{
(財今給黎病院 \\ 牧信 哉・吉 留 鶴 久 \\ 別 府 徹 已 \\ 前田病院 \\ 貴 島稔 \\ 鹿児島市立病院 \\ 谷口良康 \\ 鹿児島大学医整形外科 \\ 小倉雅・酒匂崇
}

\section{Treatment of the Intra-articular Comminuted Fractures of the Distal End of the Radius}

by

\author{
Shinya Maki, Tsuruhisa Yoshidome and Tetsumi Beppu \\ Department of Orthopaedic Surgery, Imakiire Hospital, Kagoshima \\ Yoshiyasu Taniguchi \\ Department of Orthopaedic Surgery, Kagoshima Municipal Hospital

\section{Minoru Kijima} \\ Department of Orthopaedic Surgery, Maeda Hospital, Kagoshima \\ Tadashi Ogura and Takashi Sakou \\ Department of Orthopaedic Surgery, Kagoshima University Hospital
}

\begin{abstract}
Sixteen cases of comminuted Colles' fractures were treated by pins and plaster method (10 cases) and Hoffmann-C type external fixation (six cases). Radial length and radial tilt were reduced to some extent. But external fixation method was superior as regards volar tilt. "Die punch fragment" was reduced by the combined method of external fixation and percutaneous pinning, but step-off of the radial articular surface was not always reduced by both methods. Functional results were almost good to excellent in spite of X-P evaluation. Our method of excessive traction and external fixation was usefull in early ROM acquirement.
\end{abstract}

\section{緒}

橈骨遠位端関節内に粉粋型骨折を有するいわゆる粉 粋型 Colles' 骨折は，通常の Colles'骨折が軽微な外力 で中高年の女性に多く発生するのに対し，大きな外力 で起こり青壮年の男性に多いという特長をもっている. また，粉粋型，Colles'骨折の中でも転移骨片を有する 症例は，骨片をある程度まで整得し得てもその保持が
難しいという点で治療に難渋することが多い48). 今回 われわれは, 転移骨片を有する粉粋型 Colles'骨折に対 し, pins and plaster 法) (以下，PP 法と略す）およ び Hoffmann-C 型による創外固定法 ${ }^{1}$ (以下 EF 法と 略す.）Fig. 1 にて治療を行なったのでその成績・問題 点について比較・検討した. 


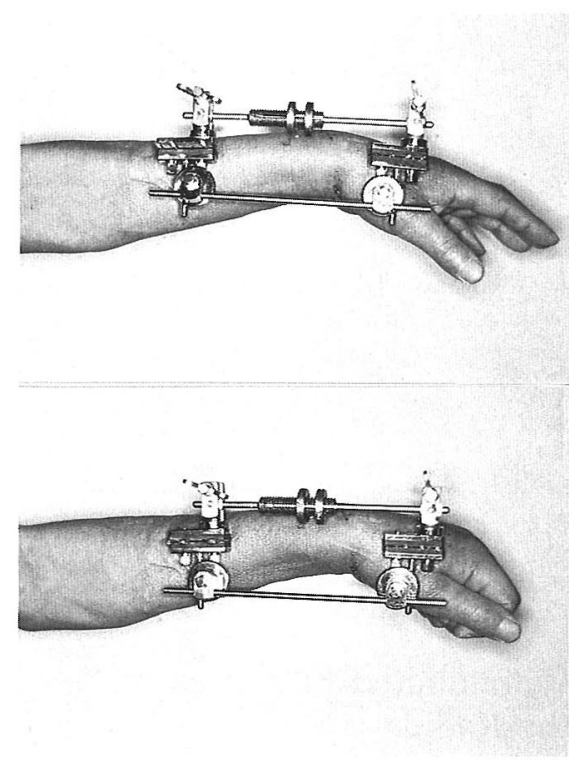

Fig. 1 Hoffmann-C 型による創外固定, 装着早期よ り手指の運動を励行させる.

\section{症例および方法}

症例は昭 60 年 1 月より昭和 62 年 3 月まで(財)今給黎 病院, 鹿大医学部付属病院など計 6 施設を受診・治療 した斎藤ら ${ }^{6}$ の提唱する粉挽型 Colles' 骨折 (Colles' 骨 折で骨折線の一部が関節内におよぶもの）のうち転位 骨片を有するものとし,いわゆる掌側および背側 Barton 骨折, Chauffer 骨折は除外した。症例は計 16 例, 男 : 14 例, 女: 2 例, 年令は 22 才〜 59 才 (平均: 46.8 才) であったが,女性 2 名を除くと他全例 22 才〜 57 才の青 壮年期の男性であった。受傷原因は全例転倒・転落の 際手をついたことによるものであった。左右差は右： 8 例, 左 $: 8$ 例, 初期の 10 例は PP 法による整復固定を 行なったが, その後の 6 例は $\mathrm{EF}$ 法を行なっている。追 跡期間は 3 力月〜29 カ月であった。

どちらの方法とも局所麻酔または腋裔神経麻酔下に 行なった.PP 法は finger trap で $3 \sim 4 \mathrm{~kg}$ の牽引をか け整復9) した後, 直径 $2 \mathrm{~mm}$ 程度の $\mathrm{K}$-wire を遠位は第 2 - 3 中手骨, 近位は橈骨の遠位 $1 / 3$ の点へ刺入し, それらを前腕一手のギプスとともにまきこみ 6 週間固 定とした. 粉粋の強い症例では pin 抜去ののち 2 週間の 前腕一手のギプス固定を追加した。

$\mathrm{EF}$ 法はレ線透視下で牽引を加え最良の整復位が得ら

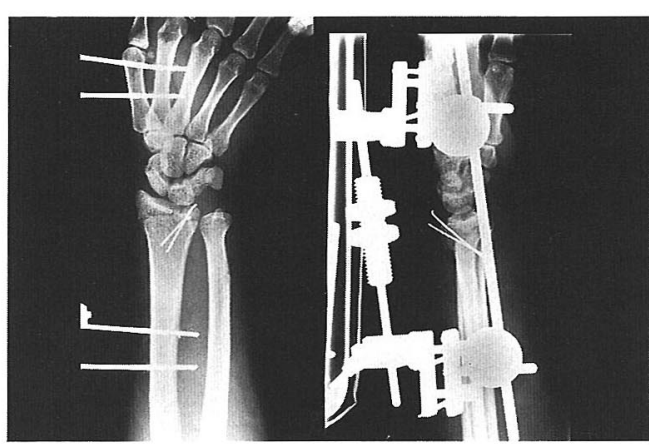

Fig. 2 橈骨一手根関節は約 $3 \mathrm{~mm}$ 開大し, “die punch fragment”は K-wire 2 本により経皮 的に固定されている。

れる手関節の肢位を確認し，その肢位で牽引・固定が できるようにねじ付の pin を, 遠位は第 2 中手骨骨幹部, 近位は橈骨の遠位 $1 / 3$ に各 2 本ずつ刺入し，橈骨一手 根関節が約 $3 \mathrm{~mm}$ 開大するまで牽引を加え固定した

(Fig. 2).この時 $\mathrm{Scheck}^{7)}$ の言う橈骨関節面背側内方 のいわゆる “die punch fragment” は経皮的に直径 1.5 $\mathrm{mm}$ の $\mathrm{K}$-wire 2 本にて整復位で固定している。麻酔が さめしだい手指の運動を励行させる。転位が生じやす いとされる術後 1 週間後にレ線にて整復位を確認し, この時率引が緩んでいる時は率引を追加した。 6 週間 後に抜釘を行なうがこの時開大した橈骨一手根関節に， 局麻剂を注入し，抜釘直後より徒手矯正による可動域 改善をはかった。

術後評価は（1)レ線評価：(1) radial length, radial tilt, volar tilt の他に“die punch fragment”および関 節面の段差 (step off) の整復状態，(2) 可動域および, Gartland の McBride system ${ }^{2)}$ による機能評価を行な った.

\section{結果}

レ線評価では radial length; PP 法 $\rightarrow 7 \mathrm{~mm} \sim 14$ $\mathrm{mm}$ (平均 $9.7 \mathrm{~mm}$ ), $\mathrm{EF}$ 法 $\rightarrow 10 \sim 14 \mathrm{~mm}$ (平均 11.5 $\mathrm{mm})$, 両群の間での有意の差はみられなかった, radial tilt ; $\mathrm{PP}$ 法 $\rightarrow 18^{\circ} \sim 26^{\circ}$ (平均 $23.4^{\circ}$ ), $\mathrm{EF}$ 法 $\rightarrow 14^{\circ} \sim 24^{\circ}$ (平均 $20^{\circ}$ ) であった。また, 術直後よりの戻りをみて みると, $\mathrm{PP}$ 法 $\rightarrow 5^{\circ} \sim+1^{\circ}$ (平均 $-1.5^{\circ}$ ), $\mathrm{EF}$ 法 $\rightarrow-2^{\circ}$ $\sim+5^{\circ}$ (平均 $+1^{\circ}$ ) であり, 有意の差はみられなかっ た. volar tilt; PP 法 $\rightarrow-25^{\circ} \sim+7^{\circ}$ (平均 $-31^{\circ}$ ), EF 法 $\rightarrow 5^{\circ} \sim 0^{\circ}$ (平均 $-0.8^{\circ}$ ), 術直後よりの戻りをみてみ 
Table 1 関節面のズレ (step off) pins and plaster洼

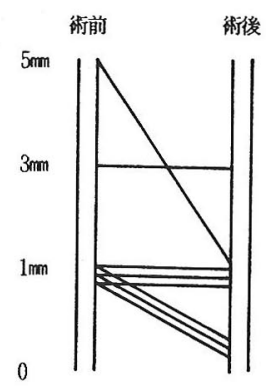

創外固定法

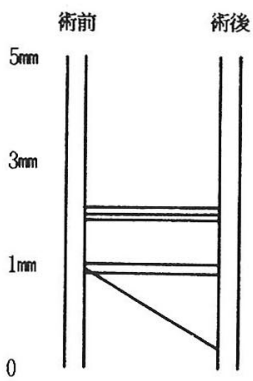

ると $\mathrm{PP}$ 法 $\rightarrow-20^{\circ} \sim+3^{\circ}$ (平均 $\left.-5.5^{\circ}\right), \mathrm{EF}$ 法 $\rightarrow-7^{\circ}$ $\sim 0^{\circ}$ (平均 $-2.8^{\circ}$ ), volar tilt の整復・保持に関しては $\mathrm{EF}$ 法の方が若干有効であるという印象を得た。16 例中 14 例で “die punch fragment”を有していたが, PP 法 では 8 例中, 7 例で受傷直後の位置とかわっていない. $\mathrm{EF}$ 法では 6 例中 5 例で受傷直後に比し改善がみられて いるが，経皮固定を行なわなかった 3 例では再転位を 生じている，逆に経皮固定をした 2 例では良い整復位 を保っていた。関節面のズレ (step off)については PP 法では $1 \mathrm{~mm}$ ～ $5 \mathrm{~mm}$ のズレがあったが, $3 \mathrm{~mm}$ 以内の ズレに関してはほとんど改善が得られていない. $\mathrm{EF}$ 法 でも $1 \mathrm{~mm} \sim 2 \mathrm{~mm}$ のズレがあったが,これも $\mathrm{PP}$ 法と 同じくほとんど改善はえられていない(Table 1).

自動可動域の平均をみてみると, PP 法； 掌㞌/背 屈 $=75^{\circ} / 56^{\circ}$, 橈屆 $/$ 尺屈 $=17^{\circ} / 34^{\circ}$, 回内 $/$ 回外 $=90^{\circ} / 75^{\circ}$, $\mathrm{EF}$ 法; 掌屈 $/$ 背屈 $=72^{\circ} / 49^{\circ}$, 橈屈 $/$ 尺屈 $=7^{\circ} / 32^{\circ}$, 回内 $/$ 回外 $=90^{\circ} / 82^{\circ}$ で $\mathrm{EF}$ 法で橈屈の回復が悪かった。これ は軽度尺屈位で固定していたためと思われる。握力を 健側対する\%でみてみると, $\mathrm{PP}$ 法； $65.4 \%, \mathrm{EF}$ 法； $52 \%$ であった.また, 掌屈/背屈で Gartlandの McBride system での許容範囲である掌屈； $30^{\circ}$, 背屈； $45^{\circ}$ まで に回復する期間をみてみると PP 法で調査しえた 6 例で は $4 \sim 6$ 週であったのに比し, $\mathrm{EF}$ 法 6 例では $1 \sim 3$ 週 と短期間で回復しているのがわかる。

Gartland の McBride system ${ }^{2)}$ による機能評価では PP 法で Excellent ; 2 例, Good ; 8 例, Fair•Poor, 0 例, EF 法で Excellent 2 例, Good ; 3 例, Fair 0 例, 再骨折の 1 例で Poor であった. 全体にしめる Excellent と Goodの割合は PP 法 ; 10/10=100\%, EF 法 ; 5/ $6=83 \%$ \%てった。

合併症としては pin からの浸出液が PP 法 10 例中 2

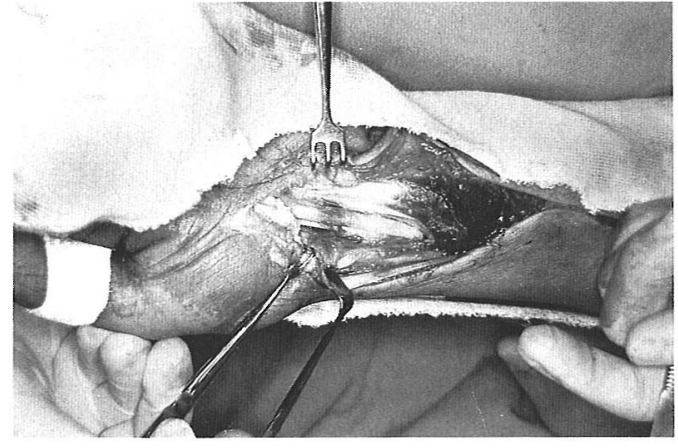

Fig. 3 正中神経は手根管の入口部で圧迫されていた。

例, EF 法 6 例中 1 例にみられたが, 局所の消毒および 抗生物質の経口投与により消退している。橈骨神経知 覚枝の刺激症状が PP 法で 1 例あったがこれも自然治瘭 している. 正中神経の不全麻痺が $\mathrm{EF}$ 法の 2 例であり, 2 例とも手根管の開放手術を行なった (Fig. 3). しか し,これは 2 例とも受傷直後より, 症状があり $\mathrm{EF}$ 法の ための合併症とは言い難い.

$$
\text { 考察 }
$$

今回,われわれは粉粋型 Colles'骨折のうち転位骨片 を有するものを PP 法ならびに EF 法にて治療した症例 を比較・検討した。レ線的には radial length, radial tilt は PP 法, EF 法ともに良好な成績が得られたが volar tilt の整復とその保持に関しては EF 法がやや優れてい るという印象をうけた。しかし，整復位といっても正 常の掌側 $10^{\circ}$ 位まで回復した症例はほとんどなかった。 また “die punch fragment”の整復に関しては Scheck 自身は牽引により整復できるとしたが，われわれの症 例では創外固定の率引によりやや整復位に戻るにしろ, すでに再転位をきたす傾向にあり，経皮的固定なり何 らかの処置が必要と思われる。

関節面のズレ (step off)では $3 \mathrm{~mm}$ 以内のズレは PP 法, EF 法いずれも改善は得られていない. Knirk ${ }^{5)} ら$ の報告では $2 \mathrm{~mm}$ 以上の step off があると将来に関節 症変化がおこるとしており，これらより $2 \mathrm{~mm}$ 以上の step off のある症例では観血的に整復する操作が必要で はないかと考える。

レ線的所見では，種々の所見がでたが機能評価では 再骨折の 1 例を除いて, Excellent〜Goodの成績を得 ている.しかし,このレポートは, Follow-up 3 カ月〜29 カ月の短期データであるのでより長い Follow-up が必 
要となろう。

最後にわれわれの粉粋型 Colles’ 骨折に対して持続的 に牽引を施す方法は，骨片を整復位に保つとともに， 関節包の拘縮を防ぎ, 早期の可動域改善を可能とした。 この骨折は通常の Colles' 骨折と異なり, 青壮年期の男 性に多いという特長を有しており，早期の職場復帰と いう点でこの方法はかなりの利点があると思われる。

\section{ま と め}

1. 転移骨片を有する粉粋型 Colles' 骨折 16 例を PP 法および EF 法で治療し比較・検討した。

2. volar tilt の整復・保持に関して創外固定が有効 であった。

3. “die punch fragment”の整復にはPP法は無 効, $\mathrm{EF}$ 法もある程度整復はできるが保持するには経皮 固定を追加すべきである。

4. 1〜3 mm の関節面のズレ (step off) は PP 法, $\mathrm{EF}$ 法でも戻しにくい.

5. 持続的に牽引を加える創外固定法により，早期 の有効な可動域の獲得が可能となった.

\section{参 考 文 献}

1) Cooney, W. P. : External fixation of distal radial fractures. Clin. Orthop. 180: 44-49, 1983.

2) Gartland, J. J. and Werley, C. W. : Evaluation of healed Colles' fractures. J. Bone Joint Surg. 33-A : 895-907, 1951.
3) Green, D. P.: Pins and plaster treatment of communited fractures of the distal end of the radius. J. Bone Joint Surg. 57-A : 304-310, 1975.

4）井上 博：橈骨末端骨折. 関節外科, $5: 11-24,1986$.

5) Knirk, J. L. and Jupiter, J. B. : Intra-articular fractures of the distal end of the radius in young adults. J. Bone Joint Surg. 68-A ; 647-659, 1986.

6）斎藤英彦・他：Colles'骨折と区別されるべき各種橈骨 末端骨折の治療とその問題点－Barton 骨折, Smith 骨 折, 粉粋 Colles'骨折を中心として. 日整会誌, $52: 43$ $-44,1978$.

7) Sheck, M. : Long term follow-up of treatment of communited fractures of the distal end of the radius by transfixation with Kirschner wires and cast. J. Bone Joint Surg. 44-A : 337-351, 1962.

8）柴田 実, 斎藤英彦: 粉粋型橈骨遠位端骨折の治療. 整・災外，25：1115-1123，1982.

9) Weber, S.C., and Szabo, R. M. : Severely communited distal radial fractures as an unsolved problem. J. Hand Surg. 11-A : 157-165, 1986.

質 問長崎大学 伊藤 博之 創外固定をしているときのX線で intercarpal lig の りかいがありましたでしょうか.

解 答 今給黎病院 牧 信哉

Intercarpal lig. の状態については今回検査しており ません。 